\title{
Pioglitazone Reduces Oxidative Stress in Kidney Against High Sucrose Diet-Induced Metabolic Syndrome in Rats
}

\section{Pioglitazon Sıçanlarda Yüksek Sükrozla Bașlatılmıș Metabolik Sendromda Böbrekteki Oksidatif Stresi Azaltır}

\author{
Ayça Bilginoğlu \\ Department of Biophysics, Faculty of Medicine, Yıldirtm Beyazıt University, Ankara, Turkey
}

\begin{abstract}
Aim: The metabolic syndrome (MS) is an important risk factor for the development of chronic kidney disease. Thiazolidinediones (TZDS) provide renovascular protection, probably in the MS. However, reports about the effect of pioglitazone on renal oxidative stress in high sucrose diet-induced MS remains to be determined. The aim of this study was to assess the effects of pioglitazone on oxidative stress markers in kidney tissues of MS rats.
\end{abstract}

Material and Method: Male Wistar rats (200-250 g in weight) were used in present study. They were divided as control (Con) group, MS group (receiving $935 \mathrm{mM}$ sucrose in drinking water) and pioglitazone treated $M S$ group (MSP) received pioglitazone treatment (30 mg/kg/day, via gavage) for two weeks at the end of the 18th weeks of MS group. Aspartate aminotransferase (AST), lactate dehydrogenase (LDH), total oxidant status (TOS), and total antioxidant status (TAS) levels were measured using commercial kits. Thiobarbituric acid reactive substances (TBARS), reduced glutathione (GSH), urea, uric acid and creatinine were measured. Thioredoxin 1 (TRX1) level was measured in cytosol and membrane tissues by western blot. TRX1 activity was measured in cytosol and membrane tissues using commercial kit.

Results: Compared with control rats, the sucrose-fed rats exhibited several characteristics of MS, including central obesity, insulin resistance, hyperinsulinemia, and hypertriglyceridemia. Furthermore, changed levels of AST, LDH, TOS, TAS, TBARS, GSH, urea, uric acid, creatinine and TRX1 activity and protein levels in the MS group were reversed to control levels by administration of pioglitazone.

Conclusion: Pioglitazone reduced the elevated oxidative stress in kidney of MS rats.

Key words: kidney; metabolic syndrome; oxidative stress; pioglitazone

\section{ÖZET}

Amaç: Metabolik sendrom (MS), kronik böbrek hastalığının ilerlemesinde önemli bir risk faktörüdür. Tiyazolidindionlar (TZDs) muhtemelen MS'de renovasküler koruma sağlar. Bununla birlikte, yüksek sükroz bașlangıçlı MS'de pioglitazonun böbreğe ait oksidatif stres

Ayça Bilginoğlu, Department of Biophysics, Faculty of Medicine, Yuldirrm Beyazat University, Ankara, Türkiye

Tel.03123241555/2065Email.draycabilginoglu@hotmail.com

Geliş Taribi: 15.05.2018 • Kabul Tarihi: 12.11.2018 üzerine etkisinin açıklanmasılla ilgili çalıșmalar devam etmektedir. Bu çalıșmanın amacı pioglitazonun MS'li sıçanların böbreklerindeki oksidatif stres belirleyicileri üzerine etkisinin incelenmesidir.

Materyal ve Metot: Çalıșmada erkek Wistar türü sıçanlar (200-250 $g$ ağırıkta) kullanıldı. Onlar kontrol grup, MS grup (935 mM sükroz içme sularına katılarak) ve pioglitazon uygulanmıș MS grup (MSP); MS grubun 18. haftasından bașlayarak 2 hafta pioglitazon (30 mg/kg/ gün, gavajla) uygulandı. Aspartate amino transferaz (AST), laktat dehidrojenaz (LDH), toplam oksidan durum (TOS), toplam antioksidan durum (TAS) seviyeleri ticari kitler kullanılarak ölçüldü. Tiyobarbitürik asit reaktif maddeler (TBARS), indirgenmiș glutatyon (GSH), üre, ürik asit and kreatin ölçüldü. Tiyoredoksin 1 (TRX1) düzeyi sitoplazma ve hücre zarında western blot ile ölçüldü. TRX1 aktivitesi sitoplazma ve hücre zarında ticari kit kullanılarak öçüldü.

Bulgular: Kontrol sıçanları ile karșılaștırıldığında, sükroz ile beslenmiș olan sıçanlar abdominal obezite, insulin direnci, hiperinsülinemi, ve hipertrigliseridemi içeren MS'nin bir çok özelliğini göstermiștir. Bunun yanında, MS'de değișmiș olan AST, LDH, TOS, TAS, TBARS, GSH, üre, ürik asit and kreatin, TRX1 aktivitesi ve protein düzeyleri pioglitazon uygulamasıyla kontrol seviyelerine dönmüștür.

Sonuç: Pioglitazon, MS'li sıçanların böbreklerinde artmıș olan oksidatif stresi azaltmıștır.

Anahtar kelimeler: böbrek; metabolik sendrom; oksidatif stres; pioglitazon

\section{Introduction}

Previous studies reported that the distribution of visceral fat is a major risk factor for cardiovascular diseases $(\mathrm{CVD})^{1}$ and chronic kidney disease $(\mathrm{CKD})^{2}$ also obesity by itself is considered an independent risk factor for the development of the $\mathrm{CKD}^{3,4}$. Furthermore, metabolic syndrome is also related with at increased risk of morbidity and mortality associated with the CVD and the development of the CKD 5 .

Peroxisome proliferator-activated receptor $\gamma(\operatorname{PPAR} \gamma)$ is a member of the nuclear hormone receptor superfamily, members of which are ligand-activated 
transcription factors related to retinoid, steroid and thyroid hormone receptors ${ }^{6}$. In addition, selective activation of PPAR $\gamma$ with specific agonists has been shown to exert therapeutic effects on cardiovascular disease, diabetes, inflammation and tumors ${ }^{7-9}$. In the case of kidney disorders, pioglitazone, a PPAR $\gamma$ agonist, is capable of protecting the kidney from ischemia-reperfusion injury by enhancing the antioxidant capacity ${ }^{10}$.

The mechanisms of impaired renal function in obesity largely remain unclear. In addition to hemodynamic factors, inflammation and oxidative stress have been implicated ${ }^{11}$, along with the decreased antioxidant defenses, represented by lower antioxidant enzymes (e.g., SOD and catalase) in the kidney in obese individuals. Oxidative stress triggered by the overproduction of reactive oxygen species (ROS) or inefficient antioxidant systems is also involved in the development of renal injury ${ }^{12}$.

The hypothesis of this study is that pioglitazone whether affects or not on the augmenter effect of MS on oxidative stress in isolated kidney from sucrose-fed induced MS rat model.

\section{Material and Method}

\section{Animals and Induction of Metabolic Syndrome}

Three-months-old male Wistar Albino rats (200-250 g) were used and maintained under standardized conditions (12-hour (h) light/dark cycle, $24 \pm 2^{\circ} \mathrm{C}, 35-$ $60 \%$ humidity). Rats were fed with standard laboratory chow with free access to water. The animals were randomly divided into the three groups consisting of 8 rats each. Control group (Con) received standard laboratory diet and drinking water. Metabolic syndrome induced group (MS) received 32\% sucrose (935 mM) including drinking water for 20 weeks ${ }^{13}$. Pioglitazone treated MS group (MSP) received pioglitazone treatment $(30 \mathrm{mg} / \mathrm{kg} /$ day, via gavage) for two weeks at the end of the $18^{\text {th }}$ weeks of MS group. Homeostatic model assessment (HOMA) is a method for assessing $\beta$-cell function and insulin resistance (IR) from basal (fasting) glucose and insulin concentrations. HOMAIR is calculated using following formule: HOMA$\mathrm{IR}=$ fasting blood glucose $(\mathrm{mmol} / \mathrm{L}) \mathrm{x}$ fasting insulin $(\mathrm{mU} / \mathrm{L}) / 22.5$. HOMA- $\beta$ is calculated using following formule: HOMA $-\beta=[20 \mathrm{x}$ fasting insulin $(\mathrm{mU} / \mathrm{L})] /$ [fasting glucose $(\mathrm{mmol} / \mathrm{L})-3.5]^{14,15}$ The units used according to IU (International units of system) Insulin and triglyceride were measured using commercial kits
(Cayman). All animal procedures and experiments described in present study were approved by the Animal Ethics Committee of Ankara University Faculty of Medicine (2015-2-37).

\section{Tissue Homogenization}

Kidneys were homogenized with a motor-driven teflon to glass homogenizer in cold (mM) TrisHCl 20 (pH 7.4), $\mathrm{NaCl} 150, \mathrm{KCl} 2$, EDTA 2, DTT 0.5, protease inhibitor cocktail 100, PMSF 0.4 and 2\% NP-40. And then centrifugation step was done to separate the cell membrane and cytosol. Protein content of cytosol was used in biochemical assays and western blot measurement.

\section{Biochemical Assays}

After homogenization of kidney tissues, protein content was analyzed using the Bradford method (Bio$\mathrm{Rad}$ ), and bovine serum albumin was used as the standard. Then, important enzymes such as lactate dehydrogenase (LDH) and aspartate aminotransferase (AST) were measured using commercial kits (Cusabio, Biovision; respectively). Total oxidant status (TOS) and total antioxidant status (TAS) such a marker of oxidative stress were determined using commercial kits (Rel assay diagnostics). Thiobarbituric acid reactive substances (TBARS) were estimated in sera as described by Wasowicz et $\mathrm{al}^{16}$. Reduced glutathione (GSH) was estimated in sera by the method as described by Ellman et $\mathrm{l}^{17}$. Markers of renal function such as urea, uric acid and creatinine were measured in sera according to the method of Berthelot reagent as described by Hammes et al. ${ }^{18}$, the method of Enzyme Colorimetric as described by Agbafor et al. ${ }^{19}$, the method as described by Barham ${ }^{20}$, respectively.

\section{Thioredoxin 1 (TRX1) protein level and activity}

Protein level of thioredoxin 1 (TRX1) was determined by Western blot. Shortly, equal amount of proteins (20 $\mu \mathrm{g}$ ) from samples were loaded and separated on $10 \%$ sodium dodecyl sulfate-polyacrylamide gel electrophoresis under reducing conditions. After electrophoresis $(150 \mathrm{~V}, 1.5 \mathrm{~h})$, the samples were electro blotted onto a PVDF membrane $(20 \mathrm{~V}, 2 \mathrm{~h})$. TRX1 contents in the samples were identified using anti-TRX1 (1/1000, rabbit, Abcam) antibody. Immunoreactive protein bands were visualized using the ECL plus detection system. TRX1 activity was measured using commercial kit (Elabscience). 
All parameters were expressed as mean \pm standard error of mean (S. E. M.). Statistical analyses were performed using one-way analysis of variance followed by Bonferroni post-hoc analysis. The $\mathrm{p}$ values less than 0.01 were considered to be statistically significant.

\section{Results}

MS animals had significantly $(\mathrm{p}<0.001)$ high glucose levels compared with control animals at the end of the 20 weeks of experimental period (Table 1). During this period, also they gain weight compared with Con group. They also showed that both the serum insulin level and triglyceride content increased significantly $(\mathrm{p}<0.001)$ compared with the Con group. HOMA (homeostasis model of assessment) index, the other marker of MS, for measuring insulin resistance increased 190\% compared with the Con group. There was a decrease of body weight in MSP group compared with MS group. Pioglitazon treatment decreased significantly the elevated blood glucose level of MS group. The serum insulin level of MSP group significantly increased $(\mathrm{p}<0.001)$ compared with Con group but it decreased significantly compared with MS group. Triglyceride content of MSP group increased compared with Con group but it decreased (not significantly) compared with MS group (Table 1).
Table 2 showed that the levels of urea, uric acid and creatinine significantly increased $(p<0.01)$ in MS group as compared to the Con group. Pioglitazone administration significantly reduced $(\mathrm{p}<0.01)$ these levels as compared to the MSP group. The activities of AST were significantly increased $(\mathrm{p}<0.01)$ in MS as compared to the Con group. MSP group showed increases (not significantly) in AST levels as compared with the Con group, but the activities of AST were decreased (not significantly) as compared to the MS. The activities of $\mathrm{LDH}$ were significantly increased $(\mathrm{p}<0.01)$ in $\mathrm{MS}$ as compared to the Con group. Pioglitazone treatment decreased (not significantly) the activities of LDH in kidney as compared to the MS rat.

Figure 1a represents TBARS as a graph in tissues of kidney. TBARS in MS group increased $(\mathrm{p}<0.01)$ as compared to the Con group. Pioglitazone treatment significantly reduced $(\mathrm{p}<0.01)$ the activities of TBARS in kidney as compared to the MS group. GSH level was shown as a graph in Figure 1b. GSH level decreased $(p<0.01)$ in MS group as compared to the Con group. Treatment of pioglitazone significantly increased $(\mathrm{p}<0.01)$ GSH level in MS group. The activities of TOS in MS and MSP group in kidney tissues showed in Figure 2a. TOS level was significantly increased $(p<0.01)$ in MS as compared to the Con

Table 1. General characteristics of animals

\begin{tabular}{lcccccc}
\hline & Body Weight $(\mathrm{g})$ & Blood Glucose $(\mathrm{mg} / \mathrm{dL})$ & Insulin $(\mathrm{ng} / \mathrm{ml})$ & Triglyceride $(\mathrm{mg} / \mathrm{dL})$ & HOMA-IR & HOMA- $\beta$ \\
\hline Con $(\mathrm{n}=8)$ & $347.11 \pm 17.31$ & $143.13 \pm 11.21$ & $1.51 \pm 0.12$ & $31.02 \pm 1.01$ & $9.31 \pm 1.32$ & $0.55 \pm 0.07$ \\
MS $(\mathrm{n}=8)$ & $449.32 \pm 8.11^{*}$ & $359.02 \pm 41.13^{*}$ & $3.12 \pm 0.21^{*}$ & $42.01 \pm 3.02^{*}$ & $25.23 \pm 2.12^{*}$ & $0.43 \pm 0.05$ \\
MSP $(\mathrm{n}=8)$ & $395.23 \pm 19.12^{*}$ & $211.22 \pm 45.11^{*}$ & $2.23 \pm 0.12^{*}$ & $40.01 \pm 1.02^{*}$ & $16.91 \pm 1.32^{*}$ & $0.45 \pm 0.04$ \\
\hline
\end{tabular}

All parameters were expressed as mean \pm standard error of mean (S. E. M.).

Con, control; MS, metabolic syndrome; MSP, pioglitazone treated metabolic syndrome group; $\mathrm{n}$, number of rats.

${ }^{*} \mathrm{p}<0.01$ versus Con

$\neq \mathrm{p}<0.01$ versus $\mathrm{MS}$.

Table 2. Biochemical parameters

\begin{tabular}{lccc}
\hline & Con $(\mathrm{n}=8)$ & MS $(\mathrm{n}=8)$ & MSP $(\mathrm{n}=8)$ \\
\hline Urea $(\mathrm{mg} / \mathrm{dL})$ & $17.6 \pm 2.3$ & $51.4 \pm 4.6^{*}$ & $30.7 \pm 3.4^{ \pm}$ \\
Uric acid $(\mathrm{mg} / \mathrm{dL})$ & $1.6 \pm 0.1$ & $6.3 \pm 0.3^{*}$ & $3.9 \pm 0.2^{ \pm}$ \\
Creatinine $(\mathrm{mg} / \mathrm{dL})$ & $0.21 \pm 0.01$ & $0.55 \pm 0.03^{*}$ & $0.32 \pm 0.04^{ \pm}$ \\
AST $(\mathrm{mU} / \mathrm{mL})$ & $0.28 \pm 0.03$ & $0.54 \pm 0.04^{*}$ & $0.39 \pm 0.05$ \\
LDH $(\mathrm{mg} / \mathrm{g})$ & $2.1 \pm 0.1$ & $3.5 \pm 0.1^{*}$ & $2.6 \pm 0.3$ \\
\hline
\end{tabular}

All parameters were expressed as mean \pm standard error of mean (S. E. M.).

AST; aspartate aminotransferase, LDH, lactate dehydrogenase, Con, control; MS, metabolic syndrome; MSP, pioglitazone treated metabolic syndrome group; $\mathrm{n}$, number of rats.

${ }^{*} \mathrm{p}<0.01$ versus Con

$\neq p<0.01$ versus MS 


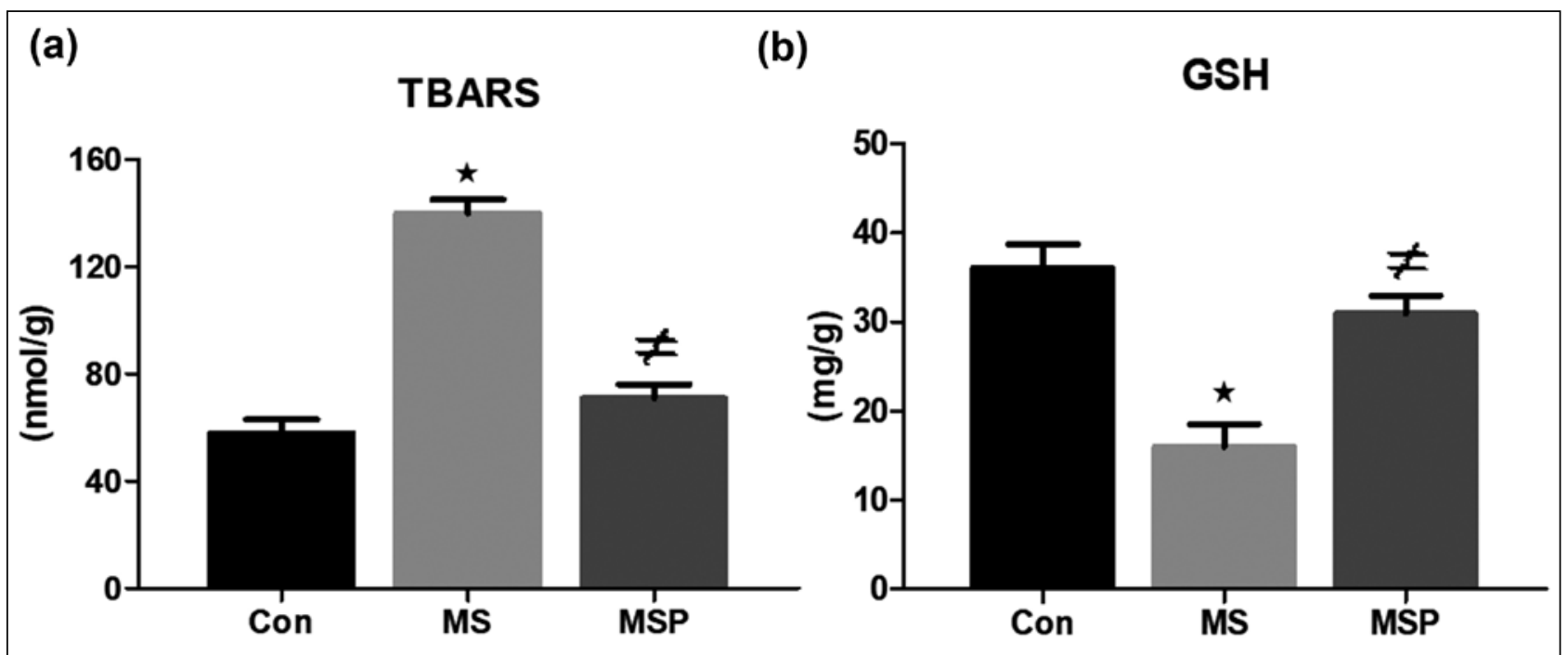

Figure 1. $\boldsymbol{a}, \boldsymbol{b}$. Changes of thiobarbituric acid reactive substances (TBARS) (a) and changes of reduced glutathione (GSH) (b) in kidney of experimental groups. Bar graph was expressed as mean \pm standard error of mean (S. E. M.) from control group (Con, $n=8$ ), metabolic syndrome group (MS, $n=8$ ), pioglitazone treated metabolic syndrome group (MSP, $n=8)$. * $p<0.01$ versus Con.

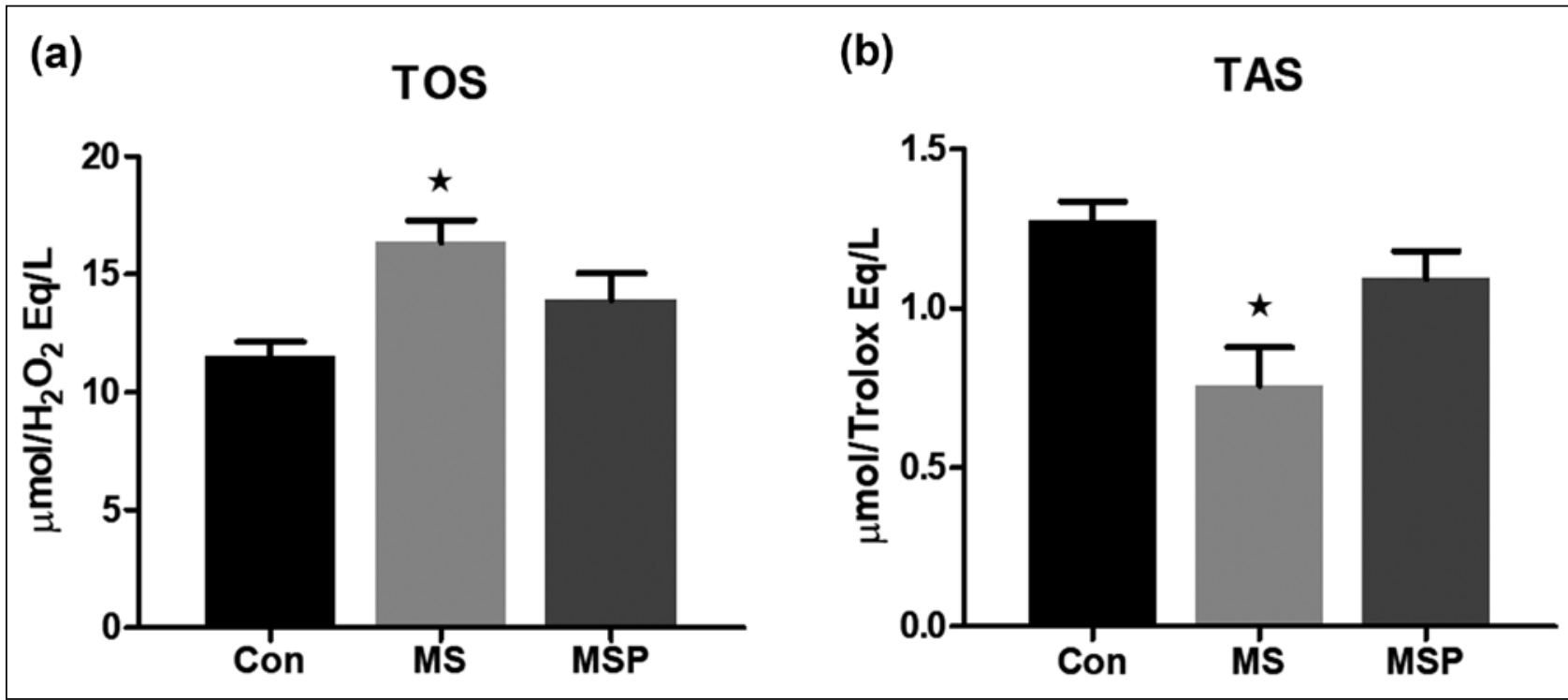

Figure 2. a, b. Changes of total oxidant status (TOS) (a) and changes of total antioxidant status (TAS) (b) in kidney of experimental groups. Bar graph was expressed as mean \pm standard error of mean (S. E. M.) from control group (Con, $n=8$ ), metabolic syndrome group (MS, $n=8$ ), pioglitazone treated metabolic syndrome group (MSP, $n=8)$. * $p<0.01$ versus Con.

group. Pioglitazone treatment decreased (not significantly) the activities of TOS in kidney as compared to the MS rat. The activities of TAS were shown as a graph in Figure $2 b$ for tissues of kidney. MS group showed significantly reduced $(\mathrm{p}<0.01)$ levels of TAS as compared to the Con group. Pioglitazone treatment restored these elevated TAS levels in kidney tissues of metabolic syndrome but not significantly.
Figure $3 \mathrm{a}$ and $3 \mathrm{~b}$ showed that TRX1 protein level significantly decreased $(p<0.01)$ in MS kidney tissues in cytosol and membrane respectively as compared to the Con group. TRX1 protein level in MSP group significantly increased $(\mathrm{p}<0.01)$ in cytosol and membrane as compared to the MS group. TRX1 activity in cytosol was lower in MS group than control group, but treatment of pioglitazone enhanced the activity 


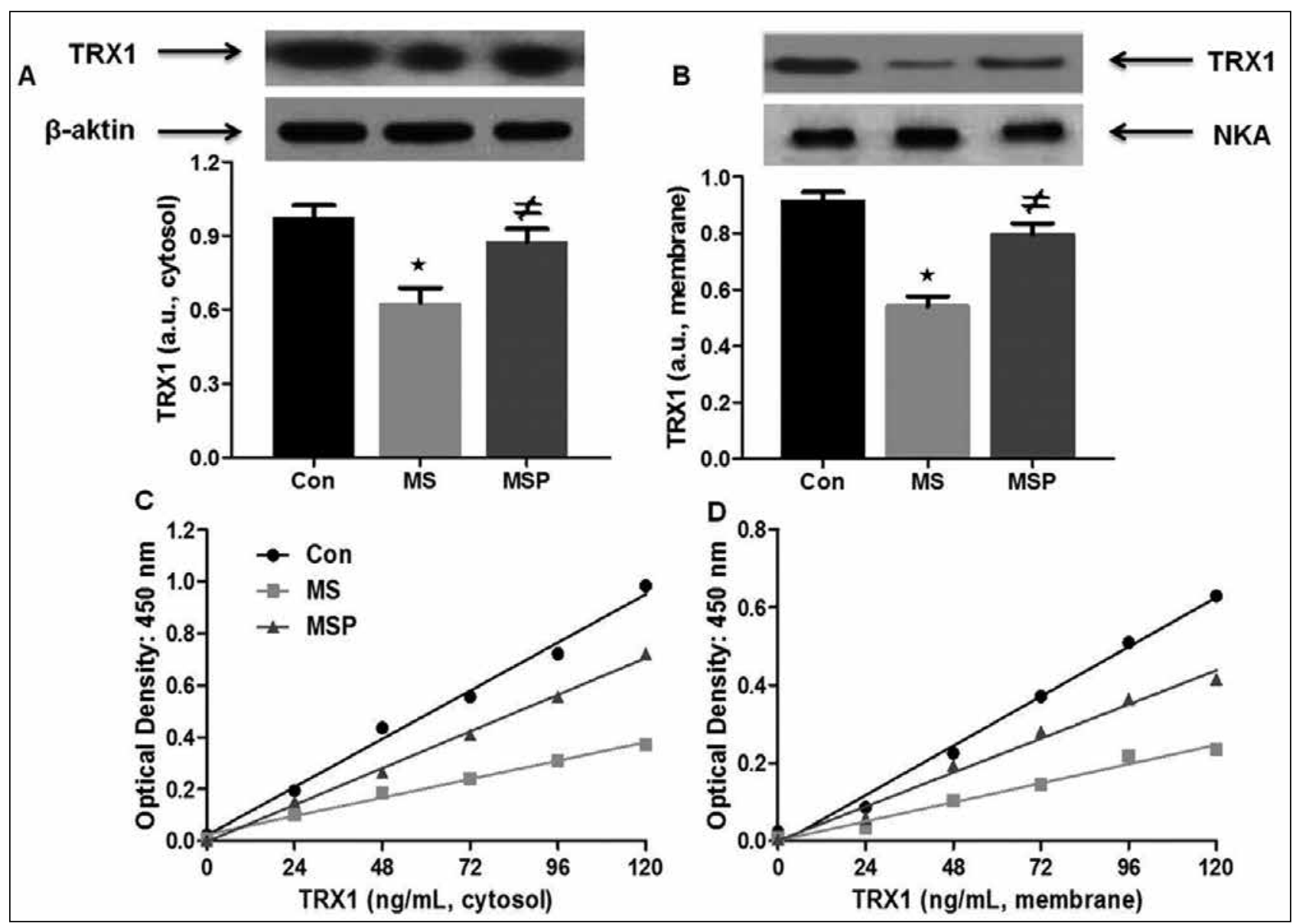

Figure 3. a-d. Representative western blots of thioredoxin 1 (TRX1) for cytosol (a) and membrane (b) of kidney tissue in experimental groups is given at the top of the bar graphs. Densitometric results are expressed as a percentage of the band obtained with control in each of the experiments. Activity of thioredoxin 1 (TRX1) for cytosol (c) and membrane (d) of kidney tissue in experimental groups. Bar graphs were expressed as mean \pm standard error of mean (S. E. M.) from control group (Con, $n=8)$, metabolic syndrome group (MS, $n=8$ ), pioglitazone treated metabolic syndrome group $(M S P, n=8){ }^{*} p<0.01$ versus Con, $\neq p<0.01$ versus MS.

of TRX1 in MS group (Figure 3c). TRX1 activity in membrane was lower in MS group than control group. Pioglitazone treatment enhanced the activity of TRX1 in MS group (Figure 3d).

\section{Discussion}

The present investigation was undertaken to assess the effect of pioglitazone on sucrose-fed-induced oxidative stress in renal system of rats. A high risk for chronic kidney disease (CKD) in patients with the metabolic syndrome has been recently reported in several investigations ${ }^{5,21}$. Our results indicated that pioglitazone may play an important role in regulation of oxidative stress in sucrose-fed induced metabolic syndrome rats.

In agreement with previous studies that investigated the effect of high sucrose diets in rodents ${ }^{22}$, we found that wistar albino rats receiving 32\% sucrose in the drinking water had higher daily water intake, higher glycemia and triglyceridemia, higher insulin resistance and higher insulin values than those observed in control animals. Pioglitazone restored these parameters to the near control levels.

Serum creatinine is an indicator of renal health, because it is an easily measured by product of muscle metabolism that is excreted unchanged by the kidney. In the present study the creatinine level of MS group increased as compared to the Con group. Urea which plays an important role in the metabolism of nitrogen containing compounds by animal and is the main nitrogen containing substance in urine of mammals, when urea is high in blood can result to tissue breakdown e.g. hemorrhage. In the present study, the 
results showed that there was a significantly increase in urea concentration in sera from MS group. The other marker of renal function is uric acid. Uric acid concentration significantly increased in sera from MS group as compared to the Con group. The levels of urea, uric acid and creatinine in kidneys of MS rat were markedly reduced after administration of pioglitazone, and these results substantiated the renoprotective effect of pioglitazone that was proposed in the previous studies. Clinical surveys and animal model experiments have revealed that raised level of AST activities are indicative of organ damage; specifically, in pathologic and toxicological events leading to cardiac and necrosis ${ }^{23,24}$. Our research showed that AST increased significantly in kidney tissues of MS group compared with the Con group. This increase may be caused by high sucrose induced damage in kidney tissues.

The LDH enzyme activity can reflect the tissue damage degree, which mainly presents in myocardium, skeletal muscle, liver, and kidneys ${ }^{25}$. The increased concentrations of LDH are indicative of cellular injury and inflammatory changes in tissues, particularly the kidney ${ }^{26,27}$. The results in LDH levels increased significantly in kidney tissues of MS group as compared with the Con group. The results showed that pioglitazone can reduce the elevated levels of both AST and LDH in kidney tissues in MS group.

Measuring plasma total antioxidant status is a sensitive and reliable marker in evaluation of the effects of different treatments such as exercise on plasma redox statu $^{28}$. In the present study, there was a significantly increase in the TOS level of kidney tissues from MS group as compared with the Con group. Furthermore, there was a significantly increase in the TAS level of kidney tissues from MS group as compared with the Con group. In results, MS in rats was associated with increased oxidative stress, indicated by the increased TBARS level and decreased endogenous antioxidant such as reduced glutathione level. These results showed that there was a level of oxidative stress in high sucrose induced $\mathrm{MS}^{29}$. It was shown that pioglitazone treatment caused a protective effect in the renal system against MS damage in rats.

Thioredoxins are ubiquitous antioxidant enzymes that play important roles in many health-related cellular processes. TRX1 is an oxidoreductase that plays an important role in maintaining intracellular thiols in a reduced state ${ }^{30}$. Our results indicated that TRX1 protein level significantly decreased in both cytosol and membrane of kidney tissues from MS group as compared with Con group. Treatment of pioglitazone significantly restored these levels in cytosol and membrane of kidney tissues from MS group to the Con group. Furthermore, activity of TRX1 in both cytosol and membrane of kidneys in MS group lower than in Con group. Pioglitazone elevated the TRX activity in MS group.

In conclusion, the current study results demonstrated that pioglitazone administration reduced the observed level of blood glucose, triglyceride, insulin resistance the other markers of MS as compared with Con group. In addition, it was also observed that pioglitazone reversed the levels of AST, LDH, TOS, TAS, TBARS, GSH, urea, uric acid and creatinine in kidney tissues of MS rats. Furthermore, TRX1 activity and protein level increased in pioglitazone treated-MS group. Our results showed that pioglitazone has protective effect in the renal system against MS induced oxidative stress in rats.

The limitation of the present study is that unfortunately, the blood pressure of metabolic syndrome induced rats could not be determined before treatment of pioglitazone and after treatment of pioglitazone. Furthermore, the urine could not be collected from experimental group to measure proteinuria and albuminuria levels.

\section{Acknowledgment}

I would like to thank Prof. Dr. Belma Turan and Dr. M. Fulya Tutar Selçuk for their departmental encouragement.

\section{Financial Support and Sponsorship}

This study was supported by TUBITAK-SBAG115 S827 and Ankara Yıldırım Beyazıt University Projects Office-2864.

\section{References}

1. Masson W, Epstein T, Huerín M, Lobo LM, Molinero G, Angel A et al. Cardiovascular risk stratification in patients with metabolic syndrome Without diabetes or cardiovascular disease: Usefulness of metabolic syndrome severity score. High Blood Press Cardiovasc Prev 2017;24(3):297-303.

2. Huh JH, Yadav D, Kim JS, Son JW, Choi E, Kim SH et al. An association of metabolic syndrome and chronic kidney disease from a 10-year prospective cohort study. Metabolism 2017;67:54-61.

3. Panwar B, Hanks LJ, Tanner RM, Muntner P, Kramer H, McClellan WM et al. Obesity, metabolic health, and the risk of end-stage renal disease. Kidney Int 2015;87:1216-22. 
4. Prasad GVR. Metabolic syndrome and chronic kidney disease: current status and future directions. World J Nephrol 2014;3:210-9.

5. Kurella M, Lo JC, Chertow GM. Metabolic syndrome andthe risk for chronic kidney disease among nondiabetic adults. J Am Soc Nephrol 2005; 16:2134-40.

6. Evans RM. The steroid and thyroid hormone receptor superfamily. Science 1988;240:889-95.

7. Peraldi P, Xu M, Spiegelman BM. Thiazolidinediones block tumor necrosis factor-alpha-induced inhibition of insulin signaling. J Clinl Invest 1997;100:1863.

8. Hallakou S, Doare L, Foufelle F, Kergoat M, Guerre-Millo M, Berthault MF et al. Pioglitazone induces in vivo adipocyte differentiation in the obese zucker $\mathrm{fa} / \mathrm{fa}$ rat. Diabetes 1997;46:1393-9.

9. Qi HP, Wang Y, Zhang QH, Guo J, Li L, Cao YG et al. Activation of peroxisome proliferator-activated receptor $\gamma$ (PPAR $\gamma$ ) through NF- $\kappa$ B/BRG1 and TGF- $\beta 1$ pathways attenuates cardiac remodeling in pressure-overloaded rat hearts. Cell Physiol Biochem 2015;35:899-912.

10. Zou C, Hu H, Xi X, Shi Z, Wang G, Huang X. Pioglitazone protects against renal ischemia-reperfusion injury by enhancing antioxidant capacity. J Surg Res 2013;184:1092-5.

11. Keaney Jr JF, Larson MG, Vasan RS, Wilson PW, Lipinska I, Corey $\mathrm{D}$ et al. Obesity and systemic oxidative stress: clinical correlates of oxidative stress in the Framingham Study. Arterioscler Thromb Vasc Biol 2003;23:434-9.

12. Elks CM, Reed SD, Mariappan N, Shukitt-Hale B, Joseph JA, Ingram DK et al. A blueberry-enriched diet attenuates nephropathy in a rat model of hypertension via reduction in oxidative stress. PLoS One $62011 ; \mathrm{e} 24028$.

13. Ruiz-Ramirez A, Chavez-Salgado M, Peneda-Flores JA, Zapata E, Masso F, El-Hafidi M. High-sucrose diet increases ROS generation, FFA accumulation, UCP2 level, and proton leak in liver mitochondria. Am J Physiol Endocrinol Metab 2011;301: E1198-207.

14. Matthews DR, Hosker JP, Rudenski AS, Naylor BA, Treacher DF, Turner RC. Homeostasis model assessment: insulin resistance and beta-cell function from fasting plasma glucose and insulin concentrations in man. Diabetologia 1985;28:4129.

15. Vasques AC, Rosado LE, Cassia GR, Geloneze B. Critical analysis on the use of the homeostasis model assessment (HOMA) indexes in the evaluation of the insulin resistance and the pancreatic beta cells functional capacity. Arq Bras Endocrinol Metabol 2008;52:32-9.

16. Wasowicz W, Nève J, Peretz A. Optimized steps in fluorometric determination of thiobarbituric acid-reactive substances in serum: importance of extraction $\mathrm{pH}$ and influence of sample preservation and storage. Clin Chem 1993;39:2522-6.
17. Ellman GL. Tissue sulfhydryl groups. Arch Biochem Biophys 1959;82(1):70-7.

18. Hammes, S. R. The further redefining of steroid-mediated signaling. Proc Natl Acad Sci 2003;100(5):21680-700.

19. Agbafor. K. N., Engwa. A. G., Ude. C. M., Obiudu. I. K. and Festus. B. O. Effect of Aqueous Leave Extract of Ageratum Conyzoides on Blood Glucose, Creatinine and Calcium ion Levels in Albino rats. Journal of pharmaceutical Chemical and Biological Sciences 2015;3(3):408-15.

20. Barham, T. Enzymatic Colorimetric Determination of Uric Acid. Journal of Clinical Chemistry 1972;97(2):142-4.

21. Chen J, Muntner P, Hamm LL, Jones DW, Batuman V, Fonseca $\mathrm{V}$ et al. The metabolic syndrome and chronic kidney disease in U. S. adults. Ann Intern Med 2004;140:167-74.

22. Soria A, D’Alessandro ME, Lombardo YB. Duration of feeding on a sucrose-rich diet determines metabolic and morphological changes in rat adipocytes. J Appl Physiol 2001;91:2109-16.

23. Adedara IA, Abolaji AO, Odion BE, Okwudi IJ, Omoloja AA, Farombi EO. Impairment of hepatic and renal functions by 2, 5-hexanedione is accompanied by oxidative stress in rats. J Toxicol 2014;2014:239240.

24. Suanarunsawat T, Ayutthaya WD, Songsak T, Thirawarapan $S$, Poungshompoo $S$ Lipid-lowering and antioxidative activities of aqueous extracts of Ocimum sanctum L. leaves in rats fed with a high-cholesterol diet. Oxid Med Cell Longev 2011;2011:962025.

25. Akila P, Asaikumar L, Vennila L. Chlorogenic acid ameliorates isoproterenol-induced myocardial injury in rats by stabilizing mitochondrial and lysosomal enzymes. Biomed Pharmacother 2017;85:582-91.

26. Quigg RJ, Cybulsky AV, Jacobs JB, Salant DJ. Anti-Fx1A produces complement-dependent cytotoxicity of glomerular epithelial cells. Kidney international 1988;34:43-52.

27. Vikramathithan J, Gautami G, Ganesh I, Srikumar K. Differences in Rat Tissue Lactate Dehydrogenase Activity Caused by Giberellic Acid and Homobrassinolide. Türk Biyokimya Dergisi [Turkish Journal of Biochemistry-Turk J Biochem] 2009;34(2):57-61.

28. Ghiselli A, Serafini M, Natella F, Scaccini C. Total antioxidant capacity as a tool to assess redox status: critical view and experimental data. Free Radic Biol Med 2000;29:1106-14.

29. Liu J, Yeo HC, Övervik-Douki E, Hagen T, Doniger SJ, Chyu DW et al. Chronically and acutely exercised rats: biomarkers of oxidative stress and endogenous antioxidants. J Appl Physiol 2000;89:21-8.

30. Yamawaki H, HaendelerJ, Berk BC. Thioredoxin: a key regulator of cardiovascular homeostasis. Circ Res 2003;93:1029-33. 